\title{
A Comparative Study of Wordsworth and Sepehri's Poetry in the Light of Ibn Arabi s Philosophy
}

\author{
Laiya Matin Parsa*
}

Islamic Azad University, Karaj Branch, Iran

Corresponding Author: Laiya Matin Parsa, E-mail: layamatinparsa@yahoo.com

\section{ARTICLE INFO}

Article history

Received: December 10, 2017

Accepted: January 09, 2018

Published: January 31, 2018

Volume: 6 Issue: 1

\section{Conflicts of interest: None}

Funding: None

\begin{abstract}
Sohrab Sepehri and William Wordsworth's poems, have repeatedly been compared as they both reflect Pantheism and Emerson's Over-Soul, yet they have never been studied in the light of Ibn Arabi's Philosophy. The theory of Constant Immanence or renewal of creation expressed by Ibn Arabi can be regarded as an umbrella term to read the selected poems of Sepehri and Wordsworth and detect the similarities between these poets of two distinct milieu. Ibn Arabi's innovative ideas of constantly renewing creation of the cosmos, the relationship between Man and Nature, Perfect Man and the love of religion have been depicted impressively centuries later in Sepehri and Wordsworth's works. There is a wide tendency to compare the poems of these two poets of different milieu due to their special outlook to nature and their very individualistic worlds and their wide acceptance by both elite and common readers of poetry.
\end{abstract}

Keywords:

Constant Immanence,

Creation,

Love Religion,

Perfect Man

\section{INTRODUCTION}

Sohrab Sepehri, (1928-1980) a popular Iranian poet and painter, was born in Kashan, a city in the center of Iran. He grew up in the unique atmosphere of that town and pursued his studies in painting in the University of Tehran. His first poems were similar to the Iranian traditional poems but in "Marge Rang" (death of colors), he oscillated between Nima's internal world and his social poems. In "Zendegi Khabha" (life of dreams), he crept into his social feelings and perception in 1953.After Mosadegh's failure and the events followed by the so-called White Revolution in Iran, he resorted to nature and tried to settle down in a natural world constantly renewed tying the poet to his creator. Such ideas can be discerned by reviewing Ibn Arabi's mystic world.

The English Romantic Poet, William Wordsworth, (17701850 ) is very similar to Sepehri in this regard. He was born in Cockermouth, Cumberland, England. Young William's parents died during his boyhood. Raised amid the mountains of Cumberland alongside the River Derwent, Wordsworth grew up in a rustic society, and spent a great deal of his childhood in nature, in what he would later remember as a particular pure relationship with nature, then in the grip of the violent French Revolution, Wordsworth's philosophical sympathies lay with the revolutionaries, but the result of the revolution let him down which was the main cause of his retreat to nature.
Both poets resorted to nature after their failure of hopes in social revolution and change. Their nature has a kind of perception and Man's evolution is due to its powers. There is a mutual interrelatedness between Man and Nature in their poetry. Unlike previous studies on Pantheism, the present study focuses on Ibn Arabi's philosophy. The footprints of Ibn Arabi's ideas have been found in both poets' works such as Sepehri's "Prayer", "Dawn Reapers" and "the Ancient Context of Night" and Wordsworth's "Tintern Abbey", "Immortality Ode", "Expostulation and Reply". Other poems have also been selected to clearly depict the ideology underlying their works with regard to Ibn Arabi's viewpoints. His Constant Immanence or renewal of creation is a concept which can be traced in both Sepehri's and Wordsworth's poems. They both attributed a special role to nature in their poems, a nature which is directly derived from God's absolute power of creation renewed constantly in Ibn Arabi's ideas.

\section{Ibn Arabi's Philosophy}

Usually known to his supporters as al-Shaykh al-akbar "the greatest Master", EBN AL-'ARABI, MOHYI-al-DIN Abu 'Abd-Allah Mohammad Ta'i Hatemi (1165-1240) is the most influential Sufi author of later Islamic history. Although the form "Ebn al-'Arabi," with the definite article, is found in his autographs and in the writings of his immediate fol- 
lowers, many later authors referred to him as 'Ebn 'Arabi', without the article, to differentiate him from Qadi Abu Bakr Ebn al-'Arabi'(Chittick 1-4).

He was born in Murcia in Spain, and his family moved to Seville when he was eight. He experienced an extraordinary mystical 'unveiling' (kashf) or 'opening' (fotuh) at about the age of fifteen which is mentioned in his famous account of his meeting with Averroes. Only after this original divine "attraction" (jadhba) did he begin disciplined Sufi practice (soluk), perhaps at the age of twenty. He studied the traditional sciences, Hadith in particular, under the supervision of many masters. He has mentioned about ninety of them in an autobiographical note (Badavi). In 597/1200 he left Spain for good, with the intention of going on Hajj. The following year in Mecca, he began writing his monumental al-Fotuhat al-makkiya under the title of The Meccan Openings which alludes to the inspired nature of the book. In 601/1204 he set off from Mecca on his way to Anatolia with Majd-al-Din Eshaq, whose son Sadr-al-Din Qunawi was Ibn Arabi's most influential disciple. After moving about for several years in the central Islamic lands, never going as far as Persia, he settled down in Damascus in 620/1223. There he taught and wrote until his death (Chittick 1-4). His proponents and even his opponents have never denied his great role to enhance theoretical issues of Islamic philosophy and theosophy. Ebn al-'Arabi was an extraordinarily prolific author. Osman Yahia attributes 850 works to him, of which 700 are extant and over 450 probably genuine. The second edition of the Fotuhat (Cairo, 1329/1911) consists of 2,580 pages, while Yahia's new critical edition is projected to include thirty-seven volumes of about100 pages each. By comparison, his most famous work, Fosus al-hekam comprises almost 180 pages. Scores of his books and treatises have been published, mostly in uncritical editions; several have been translated into European languages (Chittick 1-4).

Ibn Arabi, whose innovative ideas have been scattered among his diverse books, has always been considered a very difficult philosopher. He is a pioneer philosopher with very modern revolutionary ideas about different concepts such as 'occult language', 'unity of existence or reality', 'God's names or attributes', 'Perfect Man or the Word', 'creation or the ideology', 'union or attainment' and 'union of all religions'. His great impact on succeeding philosophers, especially 'Sufis', cannot be ignored. Even his opponents were impressed by him. Many great names among Eastern philosophers and the so-called 'Sufis' such as 'Sadr al-din Qunavi', 'Mulana jalal al-din Balkhi' and 'Khaje nasir al-din Toosi' have been impressed directly or indirectly by him. Even in the western world, although not directly and formally, Ibn Arabi is known by different artists or philosophers. One can also find traces of his ideas on Emerson and his famous essay The Over-Soul. His ideas can be easily traced in the so-called secret society of 'fedeli d'amore' and Dante's ideas, the great Italian poet. Even in the contemporary time, one can detect Ibn Arabi's impact on 'Sheikh Mahmud Tadli' and 'Sheikh Ahmad al-alavi Jazayeri', two great Islamic leaders of the contemporary world.

He has also been of great importance among academic people; one of their most popular ones is William Chittick, professor of State University of New York, whose books and articles on Ibn Arabi are quite well-known nowadays.

\section{CONSTANT IMMANENCE}

Ibn Arabi argues that God has manifestations and appearances which are constant and have no beginning or end since things are always changing constantly and God is constantly manifested in different forms and this manifestation never ends, but there is no repetition in manifestation, otherwise things, creatures and their status would not be recognized, so God is the greatest and we are like travelers toward him as Ibn Arabi says in Fotoohat:

"فنشئوون الحق هى احو ال المسافرين فللحق شئوون و لنا احوال ،

The reason that there is no repetition in manifestation is God's bilateral graciousness and estrangement attributes each of which are constantly working, so in each and every single second, things are created and destroyed at the same time. This novel creation causes evolution in cosmos which is a divine change in forms, but is static in essence (Mazaheri 280-281)

"الجوهر والموت لتبدل الصور الحيات العين “،

Focusing on the theory of Constant Immanence or Renewal of Creation, one can surprisingly find references in different cultures. For instance Isutsu states: "Constant immanence is one of the most interesting characteristics of the creation hypothesis which belongs to Ibn Arabi and it is historically important since it is a criticism to Ashariee's ideas". In Ibn Arabi's ideology, God's manifestation is an eternal constant process which contains: 1- the supreme immanence 2-the holy immanence 3- manifestation of concrete things. They all happen constantly one after another as if they are floating ruffled waves and this existence processing is repeated eternally and infinitely. In each second, the same process of annihilation and creation is repeated. Bountiful plentiful forms are generated and annihilated and are replaced by other qualities and things. So we cannot experience the same world in two sequencing moments. The world is constantly changing on a regular pattern, but it seems to us that it still is the previous world around (Mazaheri 280-281).

Ibn Arabi says that the world is newly created in every second; he calls this the Novel Creation, but it must not be assumed that this new world is opposed to the previous one. 'Novel' here means repeatable in each second. Novel Creation succinctly means the eternal recurrent process of creation (Mazaheri 282). Due to the blessings of sciences, Man can find Novel Creation alive and real. He can detect such a feeling either in his inner or outer part which means both body and mind; and this is probable by self-recognition and Man comprehends that he is constantly changing in every second during his life, but ordinary people are ignorant about Novel Creation even in their own case (Mazaher 282). Ibn Arabi describes this process as constant improvement or progress. This is an important point which can be used in studying the foundation of his thought about Novel Creation. "The most surprising thing is that he (the Man) is constantly in progress, but cannot feel it due to similarities of forms and the softness and tenderness of its veil"'(Mazaheri 282). The fact that everything is constantly renewing mainly means 
God's constant manifestation in an infinite number of potential items. This affair happens by God's descending of existence to lower stages or ranks of the cosmos. To see it differently, this constant descending process of God is the constant ascending of improving the items of the cosmos (282). In other words, improvement of items and things is nothing but the opposite side of God's descending process toward things and this fact makes them imagine that they are in progress toward their first originator (283). Novel Creation shows the active nature of Ibn Arabi's ideology. Nothing is static in this ideology and the cosmos is thoroughly in motion and changes itself spontaneously in every second and all these spontaneous motions are items moving toward progress and ascension toward their unique God. The resulting point of the Novel Creation is that we always face similar forms, but between two similar items, one differs from the other. So in manifestation there is a visible plurality, but unlike their various forms and their differences, they all return to their own united essence. We can liken this to millions of blinking shining lights in absolute darkness. If we just focus on one of these shining spots, we see that a specific light vanishes and appears again later in another position. God's sapience is like a complicated net of these bright spots whose light is constantly going on and off. It is absolutely an interesting image (285). Ibn Arabi says everything is a form of God's manifestation which is not reliant on itself. They all appear and vanish in an eternal essence. In other words, God's existence appears in billions of costumes every second. It seems a new world is created with God's each breath (286). So a question can be raised here: How can God and creation connect to each other? The answer is: God has a real existence in his own essence and an extra existence in the world of creatures. The extra existence is likened to a shadow which has covered the creatures (289). Plato's cave theory very much resembles Ibn Arbabi's ideology: Ibn Arabi's ideology whirls around two axes: the absolute God Hagh and Perfect Man in the form of ascending and descending existence. He feels free to adopt non-Islamic ideas and compromise them with Islamic ideas. He even justifies the Christian trinity in the form of unitary ideas of Islam. And this thought is extremely important for him which looks odd for a Muslim Sufi. So Abol-Ala-Affifi opposes him: "but [what can be done] our pall opposes whatever we Muslims have accepted and believed. He can adopt everything and compromise it with his own unity of existence idea, so why not follow Christianity as he has followed others" (18)?

\section{CREATION AND LOVE RELIGION}

How did we -human beings- start to exist in this world? There are different ideas and beliefs, different philosophers and prophets have talked about it. You can find a rainbow of ideas on this issue, but as far as this writing is concerned according to Ibn Arabi's ideas, "creation does not mean to create something which had not been existed before; since such a thing is impossible for both reason and action. And creation is not such a performance which God had suddenly done it all at once in the past and has left it behind, but it is such an eternal primordial movement which due to this movement, the cosmos appears in a new costume every second and different frequent variations and images (FORMS) can be applied on it, but nothing is added to it or is decreased from it" (Mazaheri 99-100).

So is creation from nonbeing? Were there any samples of creatures prior to it? One simply finds that "Ibn Arabi does not think that creation is from nonbeing and absence and without any prior sample. The creator is such an essence which is eternal and primordial and is emerged in many different variations, so creatures are these changeable mortal variations which are not fixed in their essence" (Affifi 269, qtd. In Mazhari) May not this idea remind you of Plato's ideas? Philosophers undoubtedly have repeated each other in different words. By this definition, many might doubt the originality of phenomena and think that everything is repetitive and second hand,but it is not so because if there were repetitions in emergence we would not recognize things and phenomena from each other. The secret which Dr. Mazhari mentions in Ibn Arabi's ideas is God's bilateral names and attributes. It means that God's graciousness and estrangement attributes are always cooperating with each other and they are always in action. And how can a poet create his/her imaginative world? Does it resemble the original creation? Can anyone do it? There are many questions which remain unanswered but "there is a relationship between gumption and creation in Ibn Arabi's ideas. In Ibn Arabi's theosophy, gumption is related to the creation in two ways: one is related to what we know as ultra-psychological phenomena and the other is related to what we know as gift. About the first one we should say that everyone has an imaginative power which can create whatever he wants according to his own imaginative world. In this way his imaginative creatures do not exist out of this world and appear just in his imagination and it is something common between all people.

"بالو هم يخلق كل انسان فىقوه خيالهمالاو وجودله الا فيهاو هذا هو ا هلامر العالم"

But Ibn Arabi thinks that a sage can be the source of such creation existing in the outer world using his own creative imaginative power. Both are two instances of creation in different levels. (Chittick 143, qtd. In Mazaheri) so it is a kind of creation in this world and he/she creates something using his/her gumption and such creation existed before in another level. It is not something new.

\section{"و العارف يخلق بهمته ما يكون له وجود من خار ج محل الهمهة،}

The sage's heart is like a mirror which can reflect God's face according to its owners' capability and potentiality and the image which this heart creates in the real world is something concrete and means incarnation and concretization to an imaginative creature (Curben 324, qtd. In Mazaheri). What is gumption? Ibn Arabi thinks it is the heart's theoretical consensus toward a very special target and the sage's heart can be the location of God's graciousness and estrangement incarnation. It means that heart has a hidden power which can comprehend God's realities. Such a power in a sage's heart is named gumption which has a direct relation to the creation (Mazaheriii 94).

Ibn Arabi is the supporter of ' love religion' and love is so important in his religion that most of his fundamental chief affairs of his ideas are derived from it since he has intro- 
duced the 'love religion' as the most fundamental religion and analyzes cosmos on that basis. Union of religions is another significant point for him, so he is a pioneer of thought and love in Islamic mysticism. In fact, Islamic mysticism is highly impressed by his ideas and cannot be comprehended without understanding him. Jami (1414-1492) who was a Persian poet thinks Ibn Arabi is a pioneer of the "unity of existence'. Jami, both as a prolific scholar and Sufi, is mainly known as a poet theologian of the school of Ibn Arabi whose works were thought in various schools from Samarqand to Mughal Empire. Some western thinkers think what has a vaster domain in Ibn Arabi's ideas is the unity of existence which is a thorough comprehensive concept and his other ideas are its subdivisions. He is more an intuitive spiritual mystic other than a philosopher and calls God as Hagh mostly. Ghonavi, who merged Ibn Arabi's mysticism with Mulana Jalale Al- Din's and his pupils tried to make these ideas close to philosophy.(20)In the 'Unity of Existence' discussion, Ibn Arabi should not be regarded as a philosopher,but his ideology is more of the Perfect Man. As Isutsu says: "Ibn Arabi's philosophy is succinctly a hypothetical description of all the existing world, but as it is reflected in the Perfect Man's sight; so it is an unusual ideology since it results from the unusual experience of an unusual man. (21) His method is not philosophical, and he extremely shuns philosophers and their methods and follows no one except God. (21)

\section{PERFECT MAN}

Who is perfect? What does the word perfect imply? Who does not want to claim that he/she is perfect? Everybody pretends to be perfect and decent even if he/she is not. It means an intuitive power in our inner self seduces us to move toward evolution. Some move forward positively and some in another way. However, the nature of our intention to move is the same. All religions and schools of thought have talked about it and most poets have been obsessed by such a quest. Bayazid Bastemi-prior to Ibn Arabi- and Hallaj - after him, have talked about the Perfect Man in other terms but it was Ibn Arabi who assigned a specific term for it. One can simply find such an issue in Zoroaster's and Buda's teachings. Plato, Aristotle, Nietzsche and even Marx have talked about it in different terms.

As Ibn Arabi illustrates Perfect Man, the Word refers to one who is the embodiment of both graciousness and estrangement attributes of God and who can ascend or descend as much as he wants by his/her own choice. The cosmos is like a mirror in two ways: one is the aspect that in which God can see ITS own reflection and another points to the fact that Man can find God in it (Mazaheri 72).

So this is the reason why this great sage calls human beings microcosm as the embodiment of God's attributes (Affifi 48). Ibn Arabi thinks that he and Hakim Tarmazi-Muhammed Ibn Ali Tarmazi late third century-share some viewpoints and one of these is about the Perfect Man and his position in the system of divine attributes of God. Ibn Arabi says in Fosoos-Al-Hekam: "God created the world like a dead body which is likened to a blurred dim mirror and it had to be glistened so the human being was created to be the soul of this dead body-the cosmos and refreshes it. Man is like pupil of God's eye. God looks at people and has mercies upon them. The world is standing due to Man's existence and he is like a gem on the creation's ring and is a sign which God has erected to the cosmos treasury so he is called Khalifeh or successor (Mazaheri54).

The position of the Perfect Man in this world is regarded so high as if it seems all other Creatures spin around it. As Dr. Mazaheri says in his commentary book on Naghsh al Fosoos as long as this Perfect Man exists in the world, the whole world is kept from destruction. Some are the mirrors of God's graciousness attributes and some reflect divine estrangement attributes, but the Perfect Man possesses all divine attributes and when it is talked about Man's learning of attributes means his comprehensive potentiality (Mazaheri55).

All this conveys that Perfect Man is the world's soul and the world is his body. As the soul rules the body by spiritual bodily powers, the Perfect Man can rule the cosmos by those attributes which have been taught to him, so because the manifestation of the divine attributes can succinctly be seen in Man, so the Man can be named Microcosm since God has been manifested in him and God can know himself by Man; therefore, He is the real and supreme beloved in Man's heart. The Perfect Man possesses all divine features of God. Ibn Arabi says the perfect Man does exist and the cosmos is constantly kept due to him and the Perfect Man impels a prophet. (Saeedi127)

Nasri states the same idea by Ibn Arabi in other words as follows: when God created human beings, he appointed Man as his own successor or Khalifeh and inscribed all his own divine names and attributes in him. God's necessity to creation is because of manifestation. It means that God needs the cosmos to observe his own names and attributes in creatures and other manifestations and forms. In Ibn Arabi's ideas God's relationship to cosmos is like the relationship between the shadow and its owner. It means that as the shadow does not exist by itself and its existence is dependent to its owner, the cosmos cannot exist without God. Ibn Arabi, like other mystics, thinks that one should start a spiritual journey to accomplish evolution, but in his ideas it means transformation from one point to another or from one attribute and manifestation to another. (Saeedi129) You should know that whatever has been proved in Macrocosm, must be seen in Microcosm and in this way this can be considered true since Microcosm is a replica of Macrocosm and whatever can be found in Macrocosm appears in Microcosm. (Nasafi355)

\section{ANALYSIS OF POEMS}

\section{The First Poem}

The first poem has been selected from the collection called Avaar-e-Aftaab or Debris of sun. Most of the parts of this short poem can be compared to a part of "Prayer" in "Tintern Abbey":

We crossed the light, recorded the golden field

We reaped fables and threw down faded 
Beside the sandy duns a sun caressed us like shadow, we hesitated

We beheaded dreams beside a vast mysterious riverbank A cloud arrived and we shut our eyes

Darkness broke, we saw Venus and climbed the mountain ridge

A lightening fell and observed us praying

Trembling we wept, laughing we cried

The cloud threw down a shower and we were harmonious

Blackness vanished, we rubbed our heads in the sky, and sank our heads in the "Khoor" of skies

We abandoned the shadow in valleys, cast our smile at the vast void.

Our silence joined each other, and we two become one

Our solitude stretched up to the golden field

The sun was frightened of our faces

We understood and laughed

We hid and burnt

The more closer and lonelier

We separated ourselves from the mountain ridge

I descended to earth and become God's subject

You ascended and became a god.

It can be compared to a part of "Tintern Abbey":

....And I have felt

A presence that disturbs me with the joy

Of elevated thoughts; a sense sublime

Of something far more deeply interfused,

Whose dwelling is the light of setting suns,

And the round ocean and the living air,

And the blue sky, and in the mind of man:

A motion and a spirit, that impels

All thinking things, all objects of all thought,

And rolls through all things. Therefore am I still

A lover of the meadows and the woods

And mountains; and of all that we behold

From this green earth; of all the mighty world

Of eye, and ear,-both what they half create,

And what perceive; well pleased to recognize

In nature and in the language of the sense,

The anchor of my purest thoughts, the nurse,

The guide, the guardian of my heart, and soul

Of all my moral being.

What made Wordsworth 'feel a presence' that later turned out 'to be the anchor of [his] purest thoughts' is very much similar to the sense which made Sohrab 'cross the light and record the golden field'. It seems as if Ibn Arabi's comprehensive Sapience guided both poets to the same point which they can easily feel the presence of a super power that pervades their internal and external nature. It helped Sohrab 'descend the earth and become God's subject' and convey Wordsworth that it is 'the soul of all his moral being.' These two pieces remind us of 'Perfect Man'.

\section{The Second Poem}

The second poem is "Dawn Reapers" selected from Avaar-e-Aftaab or Debris of sun:
I open the aperture to the world's expansion:

The road is bare. The tree loaded by night.

The stalk never shivers, water is too heavy to go: there's no you, no movement.

No you and every pulse a whirlpool.

No you and the roaring of streams dumb and valleys unreadable.

But as you reach: night flees from faces, the secret leaps from the world.

As you go: the grass darkens and the brooks ebullience breaks.

Closing your eyes, haziness wraps the grass.

Your face blows and the water wakes. You're passing and the mirror breathes.

The above-mentioned piece can be compared to Wordsworth's "The Immortality Ode":

Thou, whose exterior semblance doth belie Thy soul's immensity;

Thou best philosopher, who yet doth keep

Thy heritage, thou eye among the blind,

That, deaf and silent, read'st the eternal deep,

Haunted forever by the eternal mind, -

Mighty Prophet! Seer blest!

On whom those truths do rest,

Which we are toiling all our lives to find,

In darkness lost, the darkness of the grave'

Thou, over whom thy Immortality

Broods like the day, a Master o'er a slave,

A presence which is not to be put by.'

Sepehri's addressee in "Dawn Reapers" seems to be the same as Wordsworth's 'Mighty Prophet on whom the truths do rest', God's culmination of powers 'which we are toiling all our lives to find', but as [IT] reaches: 'night flees from faces, the secret leaps from the world'. The constant Sapience which, by blowing 'the water wakes, the mirror breathes', 'a presence' whose 'Immortality' is felt everywhere; the Constant Immanence of God. It is just by this presence that the nature rejuvenates.

\section{The Third Poem}

The third poem is a selected part of "the Water Footsteps".

...Love was visible, wave were visible, Snow was visible, friendship too

The word was visible

Water was visible and the reflection of objects in the water

The cool shade of cells in the heat of blood

The wet side of life

East of human inherent sorrow

Scent of solitude in the alley of seasons'.

....I am close to the beginning of earth

I pick up the pulse of flowers

I am familiar with the wet fate of water and the green habit of the tree

My soul flows towards the new direction of objects 
my soul is young

My soul sometimes coughs from joy

My soul is idle

It counts raindrops, the holes in bricks,

Sun as much as you want, union as much as you wish, multiplication as much as you want.

The poem is compared to a short poem in which Wordsworth addressed her sister: "Lines Written at a Small Distance From my House”:

It is the first mild day of March:

Each minute sweeter than before, The red-breast sings from the tall larch That stands beside our door.

There is a blessing in the air,

Which seems a sense of joy to yield

To the bare trees, and mountains bare,

And grass in the green field.

...No joyless forms shall regulate

Our living calendar:

We from to-day, my friend, will date

The opening of the year.

Love, now a universal birth

From heart to heart is stealing,

From Earth to man, from man to earth,-It is the hour of feeling.

One moment now may give us more

Than fifty years of reason;

Our minds shall drink at every pore

The spirit of the season....And from the blessed power that rolls

About, below, above;

We'll frame the measure of our souls,

They shall be tuned to love.

For both Wordsworth and Sepehri nature is somewhere, a location which can build a close relationship between man and his inner feelings. So we comprehend ourselves a lot better 'from the blessed power that rolls/we'll frame the measure of our souls' which seems to be Ibn Arabi's constant sapience rolling in nature. For both poets nature is a place for tranquility which because 'Love was visible, wave were visible, snow was visible, friendship too' it can transform a divine sense to Man as Wordsworth states: 'There is a blessing in the air/which seems a sense of joy to yield/To the bare trees, and mountains bare'. It seems that both poets have accepted Ibn Arabi's 'Love Religion' as their creed. 'Love-now a universal birth/From heart to heart is stealing/ From Earth to Man, From Man to Earth/It is the hour of feeling.'

\section{The Fourth Poem}

What follows is another selected poem by Wordsworth: "Expostulation and Reply":

Nor less I deem that there are Powers

Which of themselves our minds Impress;
That we can feed this mind of ours

In a wise passiveness'

The feeling which Wordsworth experiences very much resembles Sepehri's “The Ancient Context of Night” selected from We Nothing But Look:

A bird, which had emerged from the intimacy of darkness Took my handkerchief away

The first grit of inspiration echoed under my feet.

My blood was the dilute host of space.

My pulse floated in the elements.'

\section{The Fifth Poem}

Sample five is the poem "Tables Turned" which clearly rejects academic studies or reading books and recommends us to turn to nature which is a great teacher:

'Books! 'tis a dull and endless strife,

Come, hear the woodland linnet,

How sweet his music; on my life

There is more of wisdom in it.

And hark! How blithe the throstle sings!

And he is no mean preacher;

Come forth into the light of things,

Let nature be your teacher.'

Sepehri has a similar poem called "Both Line and Blank" from his Eighth Book or the collection called We Nothing but Look encouraging the reader to go back to nature:

One should shut the book

One should rise

And stroll alongside time,

Behold flowers

Hear ambiguity.

One should run to the end of being.

One should journey to the scent of soil of morality

One should reach the intersection of Tree and God.

One should settle

Beside expansion

Somewhere between bewilderment and intuition.

Both poets announce their firm belief in Nature and its divine powers which can play the role of the teacher, a preacher that just 'One impulse from a vernal wood/May teach you more of man/of moral evil and of good, than all the sages can.' It seems that both poets have accepted nature as a source of intuitive knowledge which pervades in the cosmos and receives direct guidance from the Divine Being or God whose powers and attributes are constantly renewed in all natural phenomena. Wordsworth shows this tendency to nature and rejection of books in different poems such as "Lines Written at a Small Distance from My house". He addresses his sister:

Then come, my sister! Come, I pray, with speed put on your woodland dress, And bring no book; for this one day We'll give to idleness. 


\section{The Sixth Poem}

Another poem by Sepehri "Presence to the End" has the same motif:

Tonight in a weird dream

It would be open towards the words.

Wind murmurs something, apple would fall

And roll on the earth's sketches and roll and roll to the absent presence of the night's home.

The canopy of a delusion would collapse.

The eye would see the plant's sad intelligence

And an ivy would twist round God's watching

The secret pours out

And the time's virtue roots withers.

On the way of darkness the water's speech verge shines,

The mirror's inner world comprehends tonight

The meaning stalk would be moved by the friend's blow

Perplexity flickers away.

At the end of the night, a bug experiments

The joyful part of loneliness.

And morning enters the morning word.

Wordsworth in the poem "It Is a beauteous Evening, Calm and Free" writes:

It Is a beauteous Evening, Calm and Free

The holy time is quiet as a Nun

Breathless with adoration; the broad sun

Is sinking down in its tranquility;

The gentleness of heaven is on the sea:

Listen! The mighty Being is awake.

And doth with his eternal motion make

A sound like thunder-everlastingly.

It seems that Sepehri's 'the friend's blow' is similar to Wordsworth's 'mighty being' which is aware in nature and shapes heavenly features on earth. If one moves toward nature and is in close relation with her rules, he/she can easily 'see the plant's sad intelligence' and 'the secret 'of the world's creation 'pours out'. They all happen on the condition that you are quiet enough as 'Nuns' to be able to hear the inner sound of nature. In Sepehri's poem 'a weird dream' is depicted. A dream which a hermit, a Sufi or a sage can also experience in the moments of ecstasy. It seems that a comprehensive Sapience as Ibn Arabi believes rules their nature and guides them to find the right path.

\section{The Seventh Poem}

In the seventh piece, Wordsworth is worried about 'What man has made of man?' in his short poem "Lines Written in Early Spring”, and amidst natural scenes while he hears 'a thousand blended notes/While in a grove' he 'sat reclined/In that sweet mood when pleasant thoughts/Bring sad thoughts to the mind' he repeats his concern and nature links 'the human soul' with natural elements and the poet grieves 'What man has made of man'. It very much resembles Sepehri's "A Message On the Way" in which the poet tries to change everything:
Someday/I will come and bring a message/Into veins I will cast light, And call out, "O you whose baskets are full of dreams!" I have brought you an apple, the red apple of the Sun. And up to the end of the poem he tries to 'reconcile' and bring good news for everyone from the 'leprous woman' to 'the blind man' and says:

I will fly kites

Water flowerpots

Go to horses and cows,

And put the green grass of love before them.

It seems that Sepehri has the same concern as Wordsworth and they both believe in such a creed as we call it Ibn Arabi's 'Love Religion'. They can change and reconcile in the circle of love which nature generously grants them. While nature grants them love and affection, they try to give it to man.

\section{CONCLUSION}

The two poets belong to very different time and location. Sepehri was born in Iran in 1928 and Wordsworth in England 1770, but the presented similar motifs, images and ideas in their works, astound the readers. The possible answer to the apparent similarity of their poems seems to lie on the similar social situations which they experienced during their youth. "The most important events of Sepehri's youth are the nationalization of the oil industry, $28^{\text {th }}$ of Mordad coup d'état of 1332 (19/08/1953) and Mosadegh's abolition from power" (Ramshini 48). To quote the poet's own diary proves the researcher's idea. Sepehri writes in his diary: "I had come to a big city, but our progress was not possible so much; we used to eat black bread in college, do exercises and talk about politics softly" (Sepehri19).

Young William Wordsworth undergoes a similar experience as Sepehri. While still at Cambridge (1790) he visits France with a close friend which seems to be the exact time of the first anniversary of the fall of the Bastille and it might be the source of the first spurts of enjoying the revolution which blossomed in the young William's heart and announced a great change and renovation of the French society and other neighboring nations and motivated the poet to return to France again. "During his year in France -17911792- Wordsworth became a fervent democrat and proselyte of the French Revolution which seemed to him as to many other generous spirits, to promise a 'glorious renovation'(Sokhanvar544). But all hopes of such young hearts as Wordsworth turned to be an illusion which left the revolutionaries disillusioned. The period 1793-5 was one of great personal unhappiness, uncertainty about his professional future, the moral and intellectual confusion. "Despite dismay at the drift of the revolution into the political terror of the Jacobin dictatorship, he held fast to his belief in the French experiment but England's declaration of war against France in 1793 left him grievously divided in his national loyalties" (Qusby 1023). Sokhanvar believes that "his gradual disillusion with the course of the revolution in France brought him to the verge of an emotional breakdown" (Sokhanvar 544).

Considering Wordsworth and Sepehri's special outlook to nature and their very individualistic worlds and due to 
their wide acceptance by both elite and common readers of poetry, there is a wide tendency to compare these two poets of different milieu with each other, so attempt was made to base the comparison on a very novel ideology by an impressive Islamic thinker and Sufi.

\section{REFERENCES}

Abjadian. A. (2002).A Survey of English Literature II. Qom: Samt.

Blades. John. (2004).Wordsworth \& Coleridge: Lyrical Ballads. China: Palgrave Macmillan.

Burgess Wilson. John. (1958). English Literature A Survey For Students. London: Richard Clay and Co LTD.

Clancey. Richard w. (2002). Wordsworth's Classical Undersong Education, Rhetoric \& Poetic Truth. U.S.A: Martin's Press, Inc.

Dr. Cowell. Raymond. (1996). Critics on Wordsworth. New Delhi: Printline.

De Selincourt. Ernest. (1970). Wordsworth, the Prelude or Growth of a Poet's Mind. New York: Oxford University Press.

Gill. Stephen. (2003) The Cambridge Companion to Wordsworth. Cambridge. United Kingdom: Cambridge University Press.

Gill. Stephen \& Wu. Duncan. (1994).William Wordsworth. New York: Oxford University Press.

Latta. Marjorie \& Greenbie. Barstow. (1917). Wordsworth's Theory of Poetic Diction: a Study of the

Historical and Personal Background of the Lyrical Ballads. New York: Yale University Press.

Sepehri.Sohrab. (1383)The Traveller; Selected Poems. Tehran: Zabankadeh Publications.

Sepehri.Sohrab. (1383) The Water's Footfall; Selected Poems: Tehran: Zabankadeh Publications.

Sokhanvar.Jalal. (1385). The Norton Anthology of English Literature. Tehran: Eshtiaghe Noor Publications.

Williams. John. (1996). William Wordsworth a Literary Life. London: Macmillan Press.

Wordsworth. William. (1994).A Selection of His Finest Poems. New York: Oxford University Press.

Zahedi. Abbas. (1383). The Traveller \& We Nothing But Look. Tehran: Zabankade Publications.

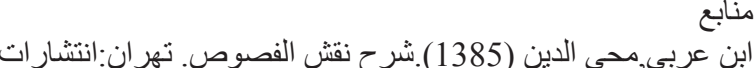

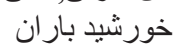

$$
\begin{aligned}
& \text { انصارى,قاسم(1387).جهان انسان شدو انسان جهان.تهران:نشر علم عتم }
\end{aligned}
$$

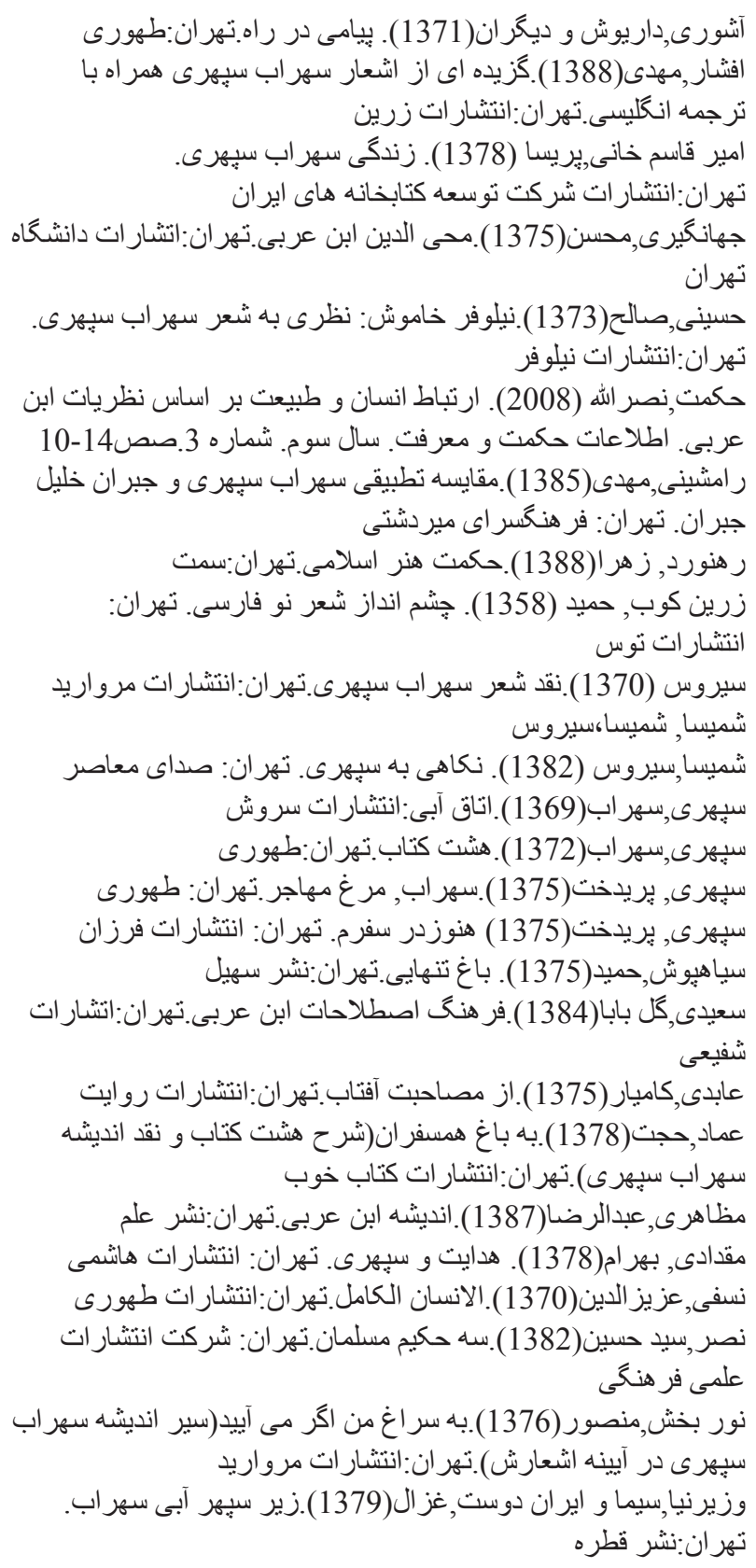

\section{Internet Sources}

Ibn Arabi and religions:< http://www.ocms.ac.uk/ docs/20050208_JClark.>

Sufism: <http://en.wikipedia.org/wiki/Sufism>

Sapience: $<$ http://en.wikipedia.org/wiki/Sapience> 